\title{
Local government as a facilitator of systemic social innovation
}

\author{
Sharon Zivkovic ${ }^{\mathrm{a}}$ \\ a Community Capacity Builders, Australia, sharon@communitycapacity.edu.au
}

\begin{abstract}
It is widely recognised that new and innovative approaches are required to address the complex, wicked problems that communities face. To tackle these challenges, local governments are developing new and innovative products, services and processes, and replicating innovations that are promoted as having been successfully implemented in other local government areas. This paper argues that approaches focusing on separate individual product, service and process innovations, and then replicating these innovations in new contexts, are not suitable for wicked problems. Instead, it is argued that local governments need to take a systemic approach to innovation when addressing wicked problems: an approach that is informed by complex adaptive systems theory that is specific to an individual community's unique needs, and utilises the community's unique resources and collective intelligence. To demonstrate this approach, a diagnostic tool for systemic social innovation which was reasoned during a project with the City of Onkaparinga is described. This tool highlights nine areas that local governments can focus upon to facilitate systemic social innovation. Five of these areas enable communities to unlock their complex adaptive system dynamics; two areas assist government systems to undertake unplanned explorations of solutions with communities; and two areas assist government systems to exploit the knowledge, ideas and innovations that emerge from community-led activities. A new research project is then described which aims to investigate if this diagnostic tool can be used to affect systemic change in a local government area.
\end{abstract}

\section{Introduction}

Many of societies' most pressing problems are wicked problems (Krawchulk 2008, p. 69): a term first coined by Rittel and Webber (1973, p. 155) to describe the complex social policy problems that societies face which cannot be definitively described and that do not have definitive and objective solutions. Examples of wicked problems include terrorism, environmental degradation, poverty (Krawchulk 2008, p. 69), ageing populations, energy security, affordable healthcare (Ho 2008), river catchment management (Ison et al. 2009, p. 4), climate change, obesity, indigenous disadvantage 
(Australian Public Service Commission 2007) and place-based disadvantage (Australian Social Inclusion Board 2011, p. 45).

The need for new and innovative approaches to address wicked problems is widely recognised (Davies, et al. 2012, p. 2). Local governments are attempting to tackle their most pressing problems by developing a variety of product, service and process innovations (Evans et al. 2012, p. 9) and replicating innovations that have been promoted as having been successfully implemented in other local government areas (Howard 2012, p. 7). By referring to the characteristics of different types of problems, this paper argues that the current local government approach of focusing upon individual product, service and process innovations, and replicating these innovations in new contexts, is not suitable for addressing wicked problems. Instead, it is argued that local government needs to take a strategic approach that interconnects product, service and process innovations when addressing wicked problems.

\section{Problem types}

The first step in addressing any problem should be to identify the problem's 'type', as different types of problems need to be addressed in different ways (Snowden \& Boone 2007, p. 4). Several typologies can be used for analysing a problem's type. For example, Kania and Kramer distinguish between technical problems on the one hand and adaptive problems on the other hand; Westley et al. (2007) differentiate between simple, complicated and complex problems; and Rittel and Webber (1973) distinguish between wicked and tame problems.

Kania and Kramer (2011, p. 39) describe technical problems as being well defined, and having a solution that is known in advance that can be implemented by one or a couple of organisations. They contrast technical problems with adaptive problems which are complex: answers are not known in advance, and even if an answer was known in advance no single organisation has the capability to address it. According to Kania and Kramer (2011, p. 38), adaptive problems can only be addressed through a 'collective impact' approach, which they define as:

long term commitments by a group of important actors from different sectors to a common agenda for solving a specific social problem. Their actions are supported by a shared measurement system, mutually reinforcing activities, and ongoing communication, and are staffed by an independent backbone organization (Kania \& Kramer 2011, p. 39.)

Kania and Kramer (2013) consider the collective impact approach to be an entirely new approach to social progress which recognises that complex issues and contexts 
require emergent rather than predetermined solutions. They argue that to be successful in taking a collective impact approach, leaders need to embrace a new way of working that focuses on creating effective rules of interaction between diverse stakeholders in order to increase the likelihood that the emergent solutions will lead to the intended goals (Kania \& Kramer 2013).

According to Westley et al. (2007), simple problems should be addressed in the way that one follows a recipe when baking a cake. This is because simple problems have clear cause and effect relationships which enable a right answer to be determined, a standardised best practice solution to be developed, and command and control management to be effective (Westley et al. 2007; Snowden \& Boone 2007). Innovations which address simple problems are therefore capable of replication in other contexts just by 'following the recipe'.

While solutions to complicated problems can also be determined in advance, complicated problems differ from simple problems in that they have many more elements and can be addressed through good practice rather than best practice (Snowden 2002, p. 106). They have clear cause and effect relationships, but because of their many parts they can have a number of right answers which not everyone can see and therefore require experts to find solutions by investigating different options (Westley et al. 2007; Snowden \& Boone 2007). Westley et al. (2007) argue that complicated problems should be addressed using the same approach as sending a rocket to the moon: developing a blueprint to specify the separate component parts and the relationships by which the parts need to be assembled to ensure critical success factors are included each time a rocket is sent to the moon. While more difficult to address than simple problems, solutions to complicated problems can be replicated in other contexts by following the blueprint.

Westley et al. (2007) liken addressing complex problems to raising a child: every child is different, following rigid protocols generally does not work and is often detrimental, and raising one child successfully does not guarantee success with raising a second child. Complex problems are unpredictable, they do not have a right answer as the problem is constantly changing, and relationships between cause and effect can only be determined in retrospect (Snowden \& Boone 2007). Complex problems are more than the sum of their parts (Snowden \& Boone 2007): there is an essence in the interacting relationships between the people, experiences and moments in time that constitute the problem (Westley et al. 2007). Solutions to complex problems are therefore not replicable as solutions are only appropriate for the specific issue, in the specific context, at the specific moment in time in which the solution was created.

Tame problems are described by Rittel and Webber (1973) as having a clear mission, all the information required for understanding and solving the problem is available, and it 
is easy to determine if the problem has been solved or not. Examples of tame problems provided by Rittel and Webber (1973, p. 160) include solving mathematical equations, chemists analysing the structure of an unknown compound, and a chess-player trying to achieve checkmate in five moves.

Rittel and Webber (1973, p. 160) argue that nearly all public policy issues are wicked problems. Characteristics of wicked problems identified by the Australian Public Service Commission (2007) include: they have no clear solution; they have many interdependencies; they are often multi-causal and have conflicting goals; they are difficult to define with different stakeholders having a different understanding of what the problem is; attempts to address them often leads to unforeseen consequences due to their multi-causality and interdependency; they are often not stable as the problem and the context of the problem evolves as attempts are made to address them; and they are socially complex, often changing their behaviours which requires stakeholders to coordinate their approaches.

\section{Addressing wicked problems}

The characteristics of the different types of problems suggest that while the local government approach of developing separate individual product, service and process innovations, and replicating innovations in new contexts would be suitable for technical, simple, complicated and tame problems, it would not be suitable for adaptive, complex and wicked problems. According to the literature, if a wicked problem is addressed as if it were a simple or complicated problem, not only would the proposed solution not work (Venton, 2011), but there is also a risk that the wicked problem could be exacerbated, as apparent solutions for wicked problems often generate undesirable consequences (Camillus 2008, p. 100; Westley et al. 2007, p. 10) and other problems (Grint 2005, p. 1473).

In a similar manner to adaptive problems requiring an emergent, collective impact approach (Kania \& Kramer 2011, p. 38), the Australian Public Service Commission (2007, p. 14) argues that wicked problems require a collaborative and holistic problemsolving approach. According to the Australian Public Service Commission (2007), stakeholders, including citizens, need to be engaged to ensure the complexity and interconnectedness of a wicked problem is understood, so that possible solutions can collectively be identified, and any required behavioural change is understood, discussed and owned by the people whose behaviour needs to change. The role of traditional leaders in addressing wicked problems is therefore not to provide the right answers, but to ask the right questions (Grint 2005 p. 1473). Grint (2005, p. 1473) provides the 
following examples of problems that have been framed to encourage the progression of a collaborative problem-solving process: 'developing a transport strategy, or an energy strategy, or a defence strategy, or a national health system or an industrial relations strategy; and developing a strategy for dealing with global terrorism'. These types of questions focus communities on developing a collaborative strategy to address a wicked problem which is specific to their unique needs, and which utilises their existing resources and collective intelligence.

The European Commission-funded Social Innovation Europe Project is promoting 'systemic innovation' as the most appropriate approach for addressing wicked problems, which it defines as 'a set of interconnected innovations, where each is dependent on the other, with innovation both in the parts of the system and in the ways that they interact' (Davies et al. 2012, p. 4). In a similar vein to Kania and Kramer's (2013) need for effective rules of interaction to increase the likelihood that emergent solutions will lead to the intended goals, the Social Innovation Europe Project argues that enabling conditions are required to instigate systemic change and that policy makers have a critical role to play in setting these enabling conditions (Davies et al. 2012, p. 17).

Complex adaptive systems theory has also been recognised as an approach for addressing wicked problems as it provides practical insights into how to strengthen communities to make them more adaptive in addressing complex social policy problems (Klijn 2008, p. 314; Australian Public Service Commission 2007, p. 14; Bentley \& Wilsdon 2003, p. 26). As with collective impact and systemic innovation, proponents of taking a complex adaptive systems approach also argue that enabling conditions need to be created. McKelvey and Lichtenstein (2007) argue that the empirical research has shown large complex systems, such as communities, require enabling conditions to be created in order to maintain the coordination required for emergent self-organisation and adaptive capability; Bentley and Wilsdon (2003, p. 26) argue that it is governments that need to take on this enabling role.

By referring to a research project undertaken in partnership with the City of Onkaparinga, this paper provides support for the assertions that wicked problems need to be addressed by taking an approach that is collaborative and holistic, that focuses on systemic innovation, that is informed by complex adaptive systems theory, and that creates the required enabling conditions to instigate systemic change. The research project aimed to investigate the impact and ways to increase the impact of the Community Capacity Builders (CCB) Community Leadership Program (CLP) which is used as the training component of the City of Onkaparinga's Leadership Onkaparinga Program. To increase the impact of the CCB CLP, a model was reasoned during the research project to create the enabling conditions required for systemic change. This 
model takes a systemic innovation approach, is informed by complex adaptive systems theory, and has the potential to be used by local governments as a diagnostic tool.

\section{The Community Leadership Program}

The CCB CLP addresses the complicated problem of providing citizens with the knowledge and skills to effectively participate in the active citizenship activities of forming collaborative community capacity building projects, bridging their projects and activities to the strategic plans of governments, and participating in community governance processes such as community visioning and strategic planning processes. Given that the CLP addresses a complicated problem, the program's design is underpinned by a blueprint: a focussed theory of change that specifies the separate component parts of the CLP and the relationships by which these component parts need to be delivered. The term 'focused theory of change' is used to describe a theory of change where the relationship between cause and effect is linear and can be clearly understood (Ebrahim \& Rangin 2010, pp. 22-23).

The program's component parts include concepts, tools and techniques from seven perspectives on how to build the capacity of communities - a health perspective, an education perspective, a welfare reform perspective, a business perspective, a sustainability perspective, a decision making perspective, and a collaborative planning perspective - and a planning process which combines techniques from the three planning processes commonly used by governments: community visioning, strategic planning, and project management. The relationships between the component parts include the seven community capacity building perspectives being embedded into the planning process, and the planning process being dived into the three sequential phases of learning about the community, taking action in the community, and sustaining the development achieved.

The CCB CLP has a complex operational strategy as it has been purposefully designed to be delivered in partnership with a government partner who provides resources and additional interventions which are required for the successful delivery of the program. An organisation's operational strategy is considered to be complex when the organisation expands its boundaries to absorb the functions of other organisations which it considers important to achieving its mission (Ebrahim \& Rangin 2010, p. 23). The CCB CLP's theory of change specifies that the government partner is required to: have a community engagement strategy in place, support participants to access and use community information for decision making, support participants to connect with local community infrastructure and community stakeholders, and to have opportunities 
available for participants to engage with other community stakeholders in community direction-setting. Examples of initiatives developed by the government partner that can occur alongside the delivery of the CCB CLP include: community visioning and planning forums, mentoring programs, community leadership networks, additional workshops using local guest speakers, and site visits to local community initiatives and infrastructure.

As shown in Figure 1, given that the CLP has a focussed theory of change and a complex operational strategy, it has been possible to measure the program's achievement of its target outcomes (Ebrahim \& Rangin 2010, pp. 25-26). This measurement was first carried out at the completion of the program's pilot. The CLP was piloted with the City of Onkaparinga from October 2006 to May 2007 with 19 City of Onkaparinga residents completing the pilot. The evaluation of the pilot found that $46 \%$ of respondents agreed, and that $54 \%$ of respondents strongly agreed that their participation in the CCB CLP had provided them with the knowledge and skills to form collaborative community capacity building projects and to bridge their projects and activities to local, regional and state strategic plans (City of Onkaparinga 2007, pers. comm., 27 July). The evaluation also found that $35 \%$ of respondents agreed, and that $65 \%$ of respondents strongly agreed that their participation in the CCB CLP had provided them with the knowledge and skills to participate in whole of community visioning and planning processes (City of Onkaparinga 2007, pers. comm., 27 July).

\section{The research project}

At the completion of the CCB CLP pilot, CCB had concerns that the CLP was not contributing towards the CCB mission of building the capacity of communities to manage change and sustain community-led development. While the evaluation of the program's pilot demonstrated that the program was achieving its desired learning outcomes, CCB had no evidence that graduates would be able to enact what they learned during the program. In order to determine the influence of the CCB CLP on graduates' practices, a research project was undertaken in partnership with the City of Onkaparinga to determine the program's influence on the community leadership practice of graduates, to determine if they were able to use what they had learned during the program to influence the organisation and communities with which they were interacting, to identify the enabling and blocking factors graduates experienced when they attempted to implement and disseminate what they had learned, and to reason a hypothesis of increasing the social impact of the program. 
The research project investigated the influence of the CCB CLP on graduates' practice, rather than attempting to measure the program's impact on graduates' practice. Measuring influence was deemed to be the most appropriate approach because the research project was investigating the relationship between the CCB CLP and graduates' practice, and from this viewpoint: the CLP has a focussed operational strategy, and the theory of change underpinning graduates' practice is complex. An operational strategy is considered to be focussed if it concentrates on a highly specific task or intervention (Ebrahim \& Rangin 2010, p. 23). When investigating the relationship between the CCB CLP and graduates' practice, the CCB CLP has a focussed operation strategy, as the program only concentrates on the knowledge and skills acquisition component of graduates' practice. A theory of change is regarded as complex when the relationships between cause and effect are only weakly understood and multiple causal factors could be at play (Ebrahim \& Rangin 2010, p. 23). This is the case for the theory of change underpinning graduates' practice, as, in addition to the influence of the CCB CLP, graduates' practice is shaped by a multitude of poorly understood and non-linear factors. As highlighted in Figure 1, when an intervention has a focused operational strategy and when what is being addressed has a complex theory of change, measuring influence is an appropriate approach to measurement.

\begin{tabular}{|c|c|c|}
\hline & \multicolumn{2}{|c|}{ Operational Strategy } \\
\hline & Focused & Complex \\
\hline 希 & $\begin{array}{l}\text { Institutional results } \\
\text { Change in societal norms and } \\
\text { policies (on rights and freedoms, } \\
\text { good governance, efficient } \\
\text { markets) } \\
\text { Measures outputs and "influence” } \\
\text { (intermediate outcomes) }\end{array}$ & $\begin{array}{l}\text { Ecosystem results } \\
\text { Economic development, } \\
\text { comprehensive rural development } \\
\text { and natural resource management, } \\
\text { collaborative development } \\
\text { Measure outcomes and impacts }\end{array}$ \\
\hline 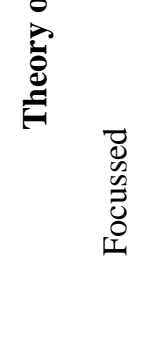 & $\begin{array}{l}\text { Niche results } \\
\text { Basic and emergency services, } \\
\text { soup kitchens, crisis drop-in } \\
\text { centres and hotlines } \\
\text { Measure inputs, activities, outputs }\end{array}$ & $\begin{array}{l}\text { Integrated results } \\
\text { Service delivery (in health, } \\
\text { education, employment), } \\
\text { immunization campaigns, complex } \\
\text { emergency services } \\
\text { Measure aggregate outputs, } \\
\text { outcomes, and sometimes impacts }\end{array}$ \\
\hline
\end{tabular}

Fig. 1. A Contingency Framework for Measuring Results Source: Ebrahim \& Rangan (2010, p. 52) 
A customised methodology was used for the research project which involved embedding into Dewey's (1938) pragmatic process of inquiry principles from grounded theory and action research. During a $2 \frac{1}{2}$ year period, biannual face-to-face semistructured interviews were undertaken with 19 graduates from the CLP. NVivo 8 software was used to transcribe the interviews and undertake line by line open coding. Theoretical reflection was then applied to the summarised data using a diverse range of theories relevant to community problem-solving to determine the influence of the program on the community leadership practice of graduates and on the ability of graduates to influence the organisations and communities with which they were interacting. Embryonic ideas for increasing the program's impact were then generated by facilitating a focus group of key stakeholders who identified interventions for addressing the enabling and blocking factors that were identified during the graduate interviews.

The most appropriate hypothesis/model for increasing the social impact of the CCB CLP was then generated using the pragmatic process of inquiry approach of converting the elements of the original situation into the unified model (Dewey 1938, p. 104) most likely to achieve the inquiry's aim (Eames 1977, p. 69). In addition to the findings from the graduate interviews and focus group, elements of the original situation included government policies, insights from the development of the CCB CLP, and theoretical literature relevant to addressing complex social policy problems.

The main analytical idea which converted elements of the inquiry's original situation into the unified model most likely to increase the social impact of the CLP was the need to improve the nature of both the interactions and the working relationships between graduates and governments, graduates and street level workers, and graduates and other community members (Zivkovic 2011). The literature explored during the research project uncovered the potential to enhance the interactions and working relationships between these community stakeholders by taking a complex adaptive systems approach when working with communities. According to complex adaptive systems theory, under certain conditions, interactions between interdependent agents produce system level order (Lichtenstein \& Plowman 2009, p. 618) as agents interact and learn from each other, change their behaviour, and adapt and evolve to increase their robustness (Gillis 2005, p. 10).

Even though communities are complex adaptive systems (Catto \& Parewick 2008, p. 125), the Australian Public Service Commissioner has expressed a desire for governments to gain a greater understanding of complexity (Briggs 2009, p. 7) and taking a complex adaptive systems approach has been recommended for addressing wicked problems (Klijn 2008, p. 314; Australian Public Service Commission 2007, p. 14; Bentley \& Wilsdon 2003, p. 26). The literature highlights that governments are reluctant 
to treat communities as complex adaptive systems (Mulgan 2001, p. 1). This reluctance is due to government challenges which are more easily met when there are clear relationships between cause and effect, such as time pressures for making government policy and the requirement of governments for simplicity, repetition, clarity, and accountability (Mulgan 2001).

\section{The model}

The model reasoned during the research project took as its starting point the need to take a complex adaptive systems approach to improving the interactions and working relationships between graduates, governments, street level workers and other community members, and the need to address the reluctance of governments to treat communities as complex adaptive systems. Duit and Galaz (2008, p. 319) and Moobela (2005, p. 35) suggest that in order for governments to be able to take a complex adaptive systems approach to community problem-solving, government systems need to have the ability to balance unplanned exploration and planned exploitation. Given this insight, the model focused on: treating communities as complex adaptive systems; balancing government's unplanned exploration of solutions with communities, and their planned exploitation of community knowledge, ideas and innovations; and creating the enabling conditions required for systemic innovation and systemic change.

From a combined analysis of the research project's findings, background information, and the theoretical literature, the model highlights nine focus areas which need to be targeted to create the enabling conditions for systemic innovation and systemic change (Zivkovic 2012). The model takes the view that while a collaborative, holistic and emergent approach is required to address wicked problems, interconnected innovations that have specific characteristics for addressing complicated problems need to be developed at the nine focus areas in order to create the required enabling conditions. The model highlighting these nine focus areas is shown in Figure 2.

Five of the model's identified focus areas and their intervention characteristics centre on where interventions will support communities to unlock their complex adaptive system dynamics (Lichtenstein \& Plowman 2009; Snowden \& Boone 2007; Surie \& Hazy 2006; Goldstein, Hazy \& Lichtenstein 2010; Uhl-Bien et al. 2008) and enable the emergence of a new and improved way of working that address the complex social policy problem that is being targeted. These five focus areas are informed by complex systems leadership theories and focus on: creating a disequilibrium state, amplifying action, encouraging self-organisation, stabilising feedback, and enabling information 
flows. The characteristics required of interventions at each of these five focus areas are listed in Table 1.

The remaining four focus areas and their intervention characteristics concentrate on enabling government systems to balance unplanned exploration and planned exploitation. Theoretical concepts that inform characteristics at these four focus areas include concepts from complex systems leadership theories (Uhl-Bien et al. 2008, p. 208; Snowden 2008; Surie \& Hazy 2006, p. 17), international relations theory (Nye 2004), and public administration theory (Lipsky 1980; Jessop 1998).

Two of these focus areas centre on where interventions can be applied to assist government systems to undertake unplanned exploration of solutions with communities. These occur at the interface between elected governments and adaptive communities, and at the interface between public administrations and adaptive communities. The characteristics required of interventions at these intervention points are listed in Table 2.

The two remaining focus areas centre on where interventions can be applied to assist government systems with the planned exploitation of knowledge, ideas and innovations that emerge from community-led activities. These occur at the interface of adaptive community innovations and elected governments and at the interface of adaptive community innovations and public administrations. The characteristics required of interventions at these intervention points are shown in Table 3.

\section{The need for further research}

While the model has been extensively peer reviewed by experts in the social innovation field, it has a significant limitation in that it has only been applied to a single case study. The model's development and application to the CCB CLP case study is described in a paper that was presented at the $3^{\text {rd }}$ EMES International Research Conference on Social Enterprise, and which was later selected for publication in the EMES Conference Selected Papers Series (Zivkovic 2011). The key theories underpinning the model and the potential utility of the model for governments is described in a paper that was presented at the $4^{\text {th }}$ International Social Innovation Research Conference (Zivkovic 2012). This paper received the Best Overall Paper Award at the conference.

In order to understand the broader potential of the model, it is proposed that a new research project be undertaken that investigates the use of the model as a diagnostic tool for creating the enabling conditions for systemic innovation and systemic change. It is argued that this project should be driven by local government, given it is recognised that governments should take on this enabling role (Davies et al. 2012, p. 17; Bentley \& 
Wilsdon 2003, p. 26) and that local government is recognised as the level of government closest to the community (United Nations 1992, p. 285). The project's research question could take the form recommended by Grint (2005, p. 1473): a broad overarching question that focuses the community on developing a strategy to address a wicked

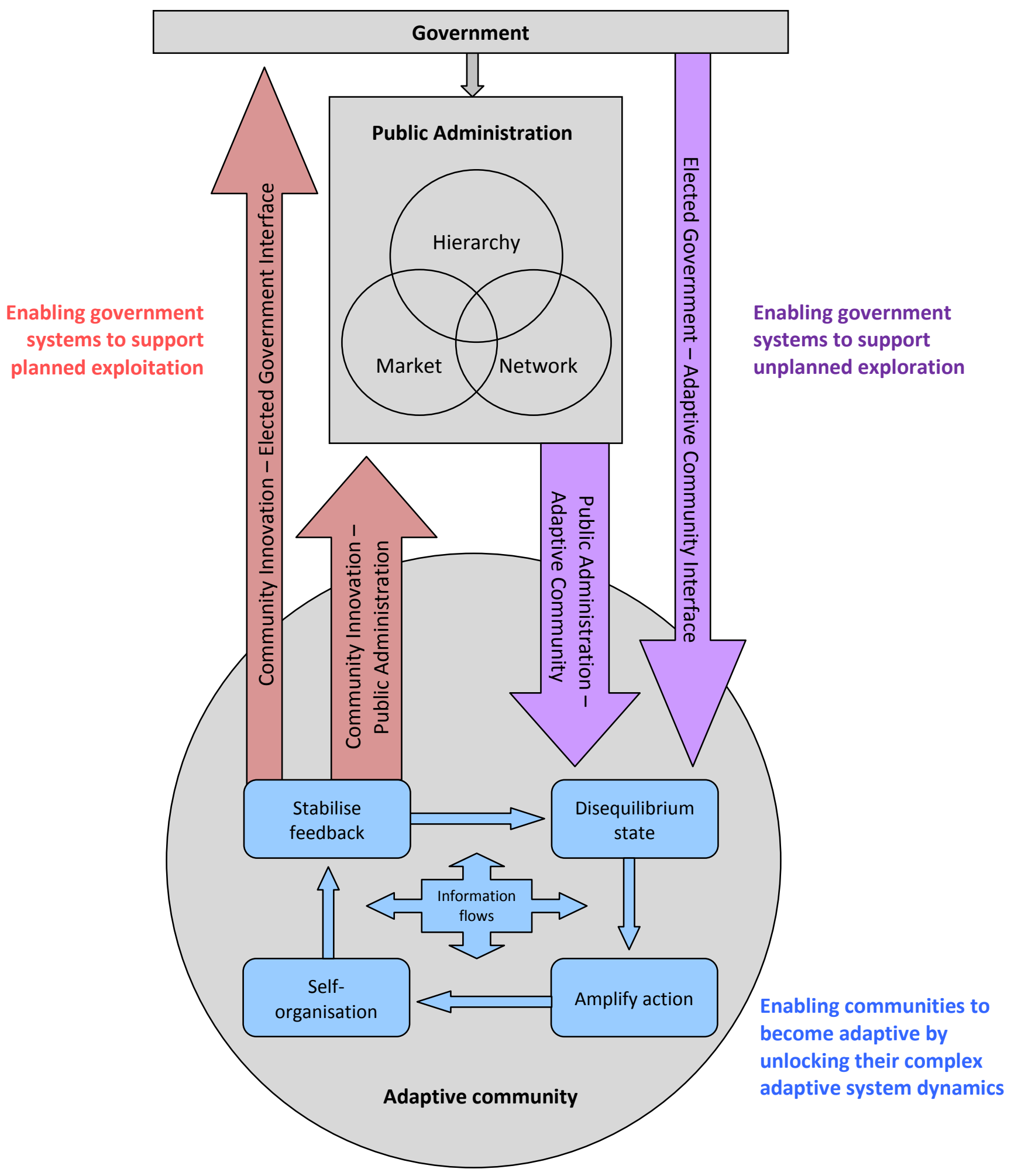

Fig. 2. Model to enable systemic innovation and systemic change 
Tab. 1. Characteristics of interventions for unlocking complex adaptive system dynamics

\begin{tabular}{|c|c|}
\hline \multicolumn{2}{|r|}{ Unlock complex adaptive system dynamics } \\
\hline Focus area & Intervention characteristics \\
\hline $\begin{array}{l}\text { Create a } \\
\text { disequilibrium state }\end{array}$ & $\begin{array}{l}\text { - } \text { highlight the need to organise communities differently } \\
\text { - cultivate a passion for action } \\
\text { - manage initial starting conditions } \\
\text { - specify goals in advance } \\
\text { - establish appropriate boundaries } \\
\text { - embrace uncertainty } \\
\text { - surface conflict } \\
\text { - create controversy }\end{array}$ \\
\hline Amplify action & $\begin{array}{l}\text { - enable safe fail experimentation } \\
\text { - enable rich interactions in relational spaces } \\
\text { - support collective action } \\
\text { - partition the system } \\
\text { - establish network linkages } \\
\text { - frame issues to match diverse perspectives }\end{array}$ \\
\hline $\begin{array}{l}\text { Encourage self- } \\
\text { organisation }\end{array}$ & $\begin{array}{l}\text { - create correlation through language and symbols } \\
\text { - encourage individuals to accept positions as role models for the change effort } \\
\text { - enable periodic information exchanges between partitioned subsystems } \\
\text { - enable resources and capabilities to recombine }\end{array}$ \\
\hline Stabilise feedback & $\begin{array}{l}\text { - integrate local constraints } \\
\text { - provide a multiple perspective context and system structure } \\
\text { - enable problem representations to anchor in the community } \\
\text { - enable emergent outcomes to be monitored }\end{array}$ \\
\hline $\begin{array}{l}\text { Enable information } \\
\text { flows }\end{array}$ & $\begin{array}{l}\text { - assist system members to keep informed and knowledgeable of forces } \\
\text { influencing their community system } \\
\text { - assist in the connection, dissemination and processing of information } \\
\text { - enable connectivity between people who have different perspectives on } \\
\text { community issues } \\
\text { - retain and reuse knowledge and ideas generated through interactions. }\end{array}$ \\
\hline
\end{tabular}

Source: Lichtenstein \& Plowman 2009; Snowden \& Boone 2007; Surie \& Hazy 2006; Goldstein, Hazy \& Lichtenstein 2010; Uhl-Bien et al. 2008.

Tab. 2. Characteristics of interventions for undertaking unplanned exploration

\begin{tabular}{ll}
\hline \multicolumn{1}{c}{ Unplanned exploration of solutions with communities } \\
\hline \multicolumn{1}{c}{ Focus area } & \multicolumn{1}{c}{ Intervention characteristics } \\
\hline $\begin{array}{l}\text { Public administration } \\
\text { - adaptive }\end{array}$ & $\begin{array}{l}\text { - assist public administrators to frame policies in a manner which enables } \\
\text { community adaptation of policies }\end{array}$ \\
$\begin{array}{ll}\text { community interface } \\
\text { - remove information differences to enable the ideas and views of citizens to } \\
\text { align to the challenges being addressed by governments } \\
\text { - encourage and assist street level workers to take into account the ideas and } \\
\text { views of citizens }\end{array}$ \\
\hline $\begin{array}{l}\text { Elected government - } \\
\text { adaptive community } \\
\text { interface }\end{array}$ & $\begin{array}{l}\text { assist elected members to frame policies in a manner which enables community } \\
\text { adaptation of policies }\end{array}$ \\
\hline
\end{tabular}

Source: Uhl-Bien et al. 2008, p. 208; Snowden 2008; Surie \& Hazy 2006, p. 17; Nye 2004; Lipsky 1980; Jessop 1998. 
problem the community faces, and that enables the community to utilise its existing resources and its collective intelligence. The strategy could then be developed by identifying existing community interventions that align to the model's nine focus areas and associated characteristics, and by developing new interventions for the focus areas where there are not sufficient interventions that have the required characteristics.

Tab. 3. Characteristics of interventions for undertaking planned exploitation

\begin{tabular}{|c|c|}
\hline \multicolumn{2}{|r|}{ Planned exploitation of community knowledge, ideas and innovations } \\
\hline Focus Area & Intervention characteristics \\
\hline $\begin{array}{l}\text { Community } \\
\text { innovation - public } \\
\text { administration } \\
\text { interface }\end{array}$ & $\begin{array}{l}\text { - encourage and assist street level workers to exploit the knowledge, ideas and } \\
\text { innovations of citizens } \\
\text { - bridge community-led activities and projects to the strategic plans of } \\
\text { governments } \\
\text { - gather, retain and reuse community knowledge and ideas in other contexts }\end{array}$ \\
\hline $\begin{array}{l}\text { Community } \\
\text { innovation - elected } \\
\text { government interface }\end{array}$ & $\begin{array}{l}\text { - encourage and assist elected members to exploit the knowledge, ideas and } \\
\text { innovations of citizens } \\
\text { - collect, analyse, synthesise, reconfigure, manage and represent community } \\
\text { information that is relevant to the electorate or area of portfolio responsibility } \\
\text { of elected members. }\end{array}$ \\
\hline
\end{tabular}

Source: Uhl-Bien et al. 2008, p. 208; Snowden 2008; Surie \& Hazy 2006, p. 17; Lipsky 1980; Jessop 1998.

\section{Conclusion}

This paper has argued that local government needs to take a systemic approach when addressing wicked problems and describes a model which has the potential to assist local governments to take such an approach. This model supports a range of approaches being promoted for addressing wicked problems including: Kania and Kramer’s (2011, p. 38) collective impact approach, the Australian Public Service Commission's (2007, p. 14) collaborative and holistic problem-solving approach, and Social Innovation Europe's systemic innovation approach. In order to understand the model's potential to be used as a diagnostic tool that assists local government to facilitate systemic innovation and systemic change in their communities, further testing of the model is required.

\section{References}

Australian Public Service Commission 2007, Tackling Wicked Problems: A Public Policy Perspective, Australian Public Service Commission, Canberra.

Australian Social Inclusion Board 2011, Governance Models for Location Based Initiatives, Department of Prime Minister and Cabinet, Canberra. 
Bentley, T. \& Wilsdon, J. 2003, 'Introduction: The Adaptive State', in T. Bentley \& J. Wilsdon (eds), The Adaptive State: Strategies for personalizing the public realm, Demos, London, pp. 13-36.

Briggs, L. 2009, 'All Those Who Stand and Wait: Putting citizens at the centre’, Public Policy, vol. 4, no. 1, pp. 1-11.

Camillus, J.C. 2008, 'Strategy as a Wicked Problem', Harvard Business Review, vol. 86, no. 5, pp. 99-106.

Catto, N.R. \& Parewick, K. 2008, 'Hazard and vulnerability assessment and adaptive planning: mutual and multilateral community - researcher communication, Arctic Canada', in D.G.E. Liverman, C.P.G. Pereira \& B. Marker (eds), Communicating Environmental Geoscience, Geological Society, London, pp. 123-40.

Davies, A., Mulgan, G., Norman, W., Pulford, L., Patrick, R. \& Simon, J. (2012), Systemic Innovation, Social Innovation Europe, viewed 19 April 2013, $<$ http://ec.europa.eu/enterprise/policies/innovation/files/social-innovation/systemicinnovation-report_en.pdf $>$.

Dewey, J. 1938, Logic: The Theory of Inquiry, Henry Holt and Co., New York, New York.

Duit, A. \& Galaz, V. 2008, 'Governance and Complexity: Emerging Issues for Governance Theory', Governance: An International Journal of Policy, Administration, and Institutions, vol. 21, no. 3, pp. 311-35.

Eames, S.M. 1977, Pragmatic naturalism: An introduction, SIU Press, Carbondale, Illinois.

Ebrahim, A. \& Rangan, V.K. 2010, The limits of nonprofit impact: A contingency framework for measuring social performance, Harvard Business School General Management Unit Working Paper, no. 10-099, Harvard Business School, viewed 16 September 2013, <http://hbswk.hbs.edu/item/6439.html>.

Evans, M., Aulich, C., Howard, A., Peterson, M. \& Reid, R. (2012), Innovation in Local Government: Defining the challenge, making the change, Australian Centre of Excellence for Local Government, University of Technology, Sydney, viewed 20 April 2013, <http://www.acelg.org.au/downloadUpdate.php?docId=169>.

Gillis, N. 2005, 'Adaptive vs. Prescriptive Policymaking: Community Empowerment through the Framework of Complexity Science', in N. Gillis \& S. Southey (eds), New Strategies for Development: A Community Dialogue for Meeting the Millennium Development Goals, Fordham University Press, Bronx, pp. 8-18.

Goldstein, J., Hazy, J.K. \& Lichtenstein, B.B. 2010, Complexity and the Nexus of Leadership: Leveraging Nonlinear Science to Create Ecologies of Innovation, Palgrave Macmillan, New York, New York. 
Grint, K. 2005, 'Problems, problems, problems: The social construction of leadership', Human Relations, vol. 58, no. 11, pp. 1467-94.

Ho, P. 2008, 'Governance at the Leading Edge: Black Swans, Wild Cards and Wicked Problems', Ethos, no. 4, pp. 74-79.

Howard, J.H. 2012, Innovation, Ingenuity and Initiative: The Adoption and Application of New Ideas in Australian Local Government, Australian Centre of Excellence for Local Government, University of Technology, Sydney, viewed 20 April 2013, $<$ http://www.acelg.org.au/downloadUpdate.php?docId=180>.

Ison, R.L., Russell, D.B. \& Wallis, P. 2009, Adaptive water governance and systemic thinking for future NRM - action research to build MDBA capability, Monash Sustainability Report 09/4, Monash University, Clayton.

Jessop, B. 1998, 'The Rise of Governance and the Risks of Failure: the Case of Economic Development', International Social Science Journal, vol. 50, no. 155, pp. 29-45.

Kania, J. \& Kramer, M. 2013, 'Embracing emergence: How collective impact addresses complexity', Stanford Social Innovation Review, weblog, viewed 15 May 2013, $<$ http://www.ssireview.org/blog/entry/embracing_emergence_how_collective_impact _addresses_complexity>.

Kania, J. \& Kramer, M. 2011, 'Collective Impact', Stanford Social Innovation Review, Winter 2011, pp. 36-41.

Klijn, E. 2008, 'Complexity Theory and Public Administration: What's New: Key concepts in complexity theory compared to their counterparts in public administration research’, Public Management Review, vol. 10, no. 3, pp. 299-317.

Krawchulk, F.T. 2008, 'Collaborative Strategic Planning and Action: A New Approach', Parameters, vol. 38, no. 2, pp. 67-78.

Lichtenstein, B.B. \& Plowman, D.A. 2009, 'The leadership of emergence: A complex systems leadership theory of emergence at successive organizational levels', The Leadership Quarterly, vol. 20, no. 4, pp. 617-30.

Lipsky, M. 1980, Street-Level Bureaucracy: Dilemmas of the Individual in Public Services, Russell Sage Foundation, New York, New York.

McKelvey, B. \& Lichtenstein, B. 2007, 'Leadership in the Four Stages of Emergence', in J. Hazy, J. Goldstein \& B. Lichtenstein (eds), Complex Systems Leadership Theory, ISCE Press, Mansfield, Massachusetts, pp. 94-107.

Moobela, C. 2005, 'From worst slum to best example of regeneration: Complexity in the regeneration of Hulme - Manchester', International Journal of Emergence, Coherence and Organisations, vol. 7, no. 1, pp. 29-42. 
Mulgan, G. 2001, 'Systems Thinking and the Practice of Government', Systemist, no. 23, pp. 22-8.

Mulgan, G., Tucker, S., Ali, R., \& Sanders, B. 2007, Social innovation: What it is, why it matters and how it can be accelerated, The Young Foundation, viewed 20 April 2013, <http://www.sbs.ox.ac.uk/centres/skoll/research/Documents/Social\%20Inno vation.pdf $>$.

Nye, J.S. 2004, Soft Power: The Means to Success in World Politics, Public Affairs, New York, New York.

Rittel, H.W.J. \& Webber, M.M. 1973, 'Dilemmas in a general theory of planning', Policy Sciences, vol. 4, pp. 155-69.

Snowden, D. 2002, 'Complex Acts of Knowing: Paradox and Descriptive Self Awareness', Journal of Knowledge Management, vol. 6, no. 2, pp. 100-11.

Snowden, D. 2008, 'Project management and system design from a complexity perspective', paper presented to KM World 2008, San Jose, 23-25 September.

Snowden, D.J. \& Boone, M.E. 2007, 'A leader's framework for decision making', Harvard Business Review, vol. 85, no. 11, pp. 69-76.

Surie, G. \& Hazy, J.K. 2006, 'Generative leadership: Nurturing innovation in complex systems’, Emergence: Complexity and Organization, vol. 8, no. 4, pp. 13-26.

Uhl-Bien, M., Marion, R. \& McKelvey, B. 2008, 'Complexity Leadership Theory: Shifting Leadership From the Industrial Age to the Knowledge Era', in M. Uhl-Bien \& R. Marion (eds), Complexity Leadership: Part 1: Conceptual Foundations, Information Age Publishing, Charlotte, North Carolina, pp. 185-224.

United Nations 1992, Agenda 21, viewed 16 May 2013, <http://sustainabledevelopment .un.org/content/documents/Agenda21.pdf>.

Venton, S. 2011, 'Why Sensemaking is Needed for Environmental Leadership’, Business Leadership Review, October 2011, viewed 17 May 2013, <http://www.mbaworld .com/blr-archive/issues-84/4/index.pdf>

Westley, F., Zimmerman, B. \& Patton, M.Q. 2007, Getting to Maybe: How the World Is Changed, Vintage Canada, Toronto.

Zivkovic, S. 2011, ‘Addressing Society’s Most Pressing Problems by Combining the Heroic and Collective Forms of Social Entrepreneurship', EMES Conference Selected Papers Series, Social Innovation through Social Entrepreneurship in Civil Society Conference, EMES European Research Network, Denmark, pp. 1-22.

Zivkovic, S. 2012, 'Government's role in social innovation: Balancing unplanned exploration and planned exploitation', paper presented to the $4^{\text {th }}$ International Social Innovation Research Conference, Birmingham, 12-14 September. 